Игорь Плохута,

Національний університет оборони України імені Івана Черняховського, м. Київ

ORCID ID 0000-0002-6556-294X

Михайло Орда, кандидат технічних наук, старший науковий співробітник Національний університет оборони України імені Івана Черняховського, м. Київ

ORCID ID 0000-0003-0374-3881

DOI: 10.33099/2617-1775/2020-02/250-259

\title{
ЗАГАЛЬНІ ПРОБЛЕМИ ТА ПЕРСПЕКТИВИ РОЗВИТКУ ВИЩОЇ ОСВІТИ В УКРӒ̈НI
}

У статті розглянуто існуючий стан $і$ загальні проблеми, які пов'язані з необхідністю розроблення та впровадження заходів задля забезпечення якості вищої освіти в Україні, визначення стратегї подальшого розвитку вищих навчальних закладів. Приділено увагу перспективам розвитку вищої освіти, виходячи із загальних реформ освітянської сфери.

Ключові слова: освіта; вища освіта; освітній прочес; державне регулювання вищої освіти.

Постановка проблеми. Освіта створює умови та забезпечує можливості для розвитку свідомості молодої людини як особистості та професіонала у обраному напрямку навчання, формує інтелектуальний, науковий та творчий потенціал суспільства, є фундаментальним видом інвестування у людський капітал на макрорівні. Адже світ давно зрозумів, що якість освіти у високотехнологічному інформаційному суспільстві стає головним аргументом людського розвитку, а також забезпечення такого рівня життєвої та професійної компетентності людини, який задовольняє їі прагнення до самовдосконалення і саморозвитку [6].

Крім того, високий рівень освітніх послуг забезпечує потреби суспільства в освічених i висококультурних громадянах. Перебуваючи у залежності від економічного і політичного розвитку держави, вища освіта одночасно сама активно впливає на всі процеси, які відбуваються у країні. Чим вищий відсоток осіб з вищою освітою, тим успішніше розвивається суспільство. Для більш розвинених країн характерним є високий відсоток осіб, які мають вищу освіту [5]. За цим показником Україна відстає від провідних країн світу - лише понад 28\% громадян мають вищу освіту, в той час як в інших країнах Свропи цей показник становить 40 - 50\%. За даними Свропейської комісії, уже в 2020 р. не менше ніж $35 \%$ робочих місць у країнах-членах Свропейського Союзу вимагатимуть мати вищу освіту [2].

Стосовно України, ми вже зараз відчуваємо, що освіченість населення не повністю відповідає сучасним запитам економічного, політичного та соціальнокультурного розвитку держави. Можна сміливо стверджувати, що невисокий професійний й загальнокультурний рівень переважаючої кількості населення, особливо молоді, ставить під загрозу не тільки перспективи економічного росту, але й соціальну стабільність. Тому виявлення основних проблем системи вищої 
освіти та пошук шляхів iї модернізації $\epsilon$ надзвичайно актуальним питання українського сьогодення.

Аналіз останніх досліджень і публікацій. Питання, які пов'язані 3 дослідженням важливості освіти, зокрема вищої, задля підвищення рівня економічного розвитку України розглядались великою кількістю авторів, зокрема такими як: Архипова С., Буличева Н., Пивовар Ю., Богачевська І., Карпенко М., Кудрявцева О., Радомська Л., Стадній А., Турчин Я. та іншими.

Мета статті. Виявлення загальних проблем та обгрунтування основних напрямів модернізації системи вищої освіти в Україні.

Методи дослідження. Дослідження проведене iз застосуванням таких теоретичних методів: системний аналіз вітчизняного та міжнародного досвіду щодо розв’язання проблем вищої освіти, індукція та дедукція, порівняння, узагальнення та систематизація.

Виклад основного матеріалу. Вища освіта є складовою системи освіти України, що регулюється Законами України «Про освіту» та «Про вищу освіту». Вона забезпечує фундаментальну наукову, професійну та практичну підготовку тих, хто навчається, і $\epsilon$ важливою соціальною ланкою у державі. Модернізація вищої освіти в Україні вимагає подолання низки проблем, серед яких найбільш актуальними є: невідповідність діючої в Україні системи освіти сучасним реаліям; старіння викладацького складу; недостатнє фінансування та неефективність використання ресурсів освіти; невідповідність структури підготовки спеціалістів реальним потребам економіки; зниження якості освіти; корупція в системі вищої освіти; відірваність від наукових досліджень; повільні темпи інтеграції в європейський і світовий інтелектуальний простір [8]. Фахівці також вказують на значне розширення системи вищої освіти, що відбувалося в Україні з середини 1990-х років, маючи на увазі як збілышення самої кількості вищих навчальних закладів, так і стрімке зростання загальної кількості студентів і випускників закладів вищої освіти (далі - ЗВО).

Зі швидким розростанням системи вищої освіти прямо й опосередковано пов’язуються такі проблеми, як руйнування системи професійно-технічної освіти, дефіцит кваліфікованих кадрів робітничих спеціальностей, неможливість для багатьох випускників ЗВО знайти роботу за фахом, інфляція освітніх і професійних стандартів, надмірне навантаження на викладачів та недостатнє фінансування університетів, зростання рівня корупції у ЗВО та інші.

Якщо для прикладу розглянути підготовку економістів, вірніше скільки їх зараз, то можемо констатувати, що існує значна кількість ЗВО, які випускають лише економістів. Тепер питання, де їх усіх працевлаштовувати? Якщо у нас і так багато спеціалістів у цій галузі, то чому щороку виникають проблеми 3 державним бюджетом? Тож якщо ми зменшимо кількість усіх вишів, і лише декілька 3 них у країні будуть випускати кваліфікованих економістів, то ми можемо уникнути кризи нераціонального використання бюджетних коштів, у тому числі загальної економічної кризи, яку зараз маємо. Ось що є першою та саме головною проблемою вищої освіти.

Але ця проблема породжує й іншу проблему - масове здобуття усіма бажаючими вищої освіти. Тоді виникає питання кому потрібне таке масове навчання? Ми випускаємо дипломованого спеціаліста, який навіть на заняття рідко ходив, але в кінці навчання має гарні оцінки і отримує диплом бакалавра, а то і магістра. А тепер задумайтесь, якщо це 
майбутній хірург, який буде Вас оперувати, чи архітектор побудує Вам оселю, то хіба 3 такими спеціалістами ми хочемо мати справу? I проблема не в самих студентах, а в ставленні до якості вищої освіти. Адже, із цілої маси випускників лише одиниці підуть працювати за спеціальністю.

На сьогоднішній день освіта є одним із найважливіших факторів, який забезпечує економічний розвиток України. Відповідно до щорічного звіту ООН конкурентоспроможність країн світу визначатиметься не природними i навіть не фінансовими ресурсами, а кваліфікацією робочої сили. [4].

Відповідно до Закону України «Про національну безпеку України» одним 3 найважливіших пріоритетів національних інтересів держави $є$ розвиток інтелектуального потенціалу суспільства та запобігання відтоку вчених, фахівців і кваліфікованої робочої сили з України. Саме цей фактор найбілыш виразно впливає на ефективне регулювання та перебіг процесів, що нині відбуваються в галузі науки та освіти й є однією з головних причин невирішених проблем в системі надання якісних освітніх послуг. Зволікання з їх вирішенням ведуть до зниження якості підготовки студентів i, як наслідок, зниження іххьої конкурентоспроможності на внутрішньому та зовнішніх ринках праці.

Однією $з$ найгостріших проблем освіти є невідповідність діючої в Україні системи освіти сучасним реаліям. Українська освіта почала модернізацію безпосередньо 3 виконанням Болонських домовленостей, їі інтеграцією в європейський освітній простір [7]. В Україні активний розвиток Болонського процесу розпочався фактично з прийняття Міністерством освіти і науки України наказу від 23.01.2004 № 49. «Про затвердження Програми дій щодо реалізації положень Болонської декларації в системі вищої освіти і науки України на 2004 - 2005 роки». До 2010 року було заплановано створення єдиного європейського наукового й освітнього простору задля розширення можливостей випускників, збільшення мобільності громадян на європейському ринку праці та конкурентоздатності у порівнянні з європейською вищою школою.

Для досягнення цієї мети згаданий процес передбачав: прийняття зручної та зрозумілої градації дипломів, ступенів і кваліфікацій; запровадження двоступеневої структури вищої освіти; запровадження визнаного на європейському просторі вченого ступеня доктора філософіï; використання єдиної системи кредитних одиниць ECTS (European Credit Transfer System); напрацювання та підтримування європейських стандартів якості із застосуванням порівняльних критеріїв, механізмів і методів їх оцінки відповідно до вимог ENQA; усунення наявних перешкод для збільшення мобільності студентів, викладачів, дослідників і управлінців вищої школи [9].

За роки незалежності України не раз робилися спроби реанімувати стару систему вищої освіти, розраховану на забезпечення країни фахівцями на базі не менш значних матеріально-технічних ресурсів. Однак, ці спроби виявилися марними. Загалом можна сказати, що за роки незалежності ситуація у сфері вищої освіти значно погіршилась. Вже практично 20 років відбувається процес вилучення інтелектуальних ресурсів в інші сфери діяльності, а найжахливіше те, що найкваліфікованіші і найталановитіші з них взагалі залишають Україну назавжди.

Оскільки, бюджетні витрати на науку не зростають, все більший відсоток науковців зосереджується саме у ЗВО. На сьогодні, після радянської епохи, в Україні всього близько 28\% населення здобули вищу освіту. Слід зазначити, що згідно з прогнозами 
ЮНЕСКО в XXI ст. цивілізованого рівня добробуту досягнуть тільки країни, в яких 40 $50 \%$ працездатного населення буде мати якісну вищу освіту. Від рівня технологічного розвитку кожної країни залежить не тільки їі економічна могутність і рівень життя населення, але і становище цієї країни в світовій спільноті, можливості економічної і політичної інтеграції з іншими країнами, а також розв'язання проблем національної безпеки.

У той же час рівень розвитку і використання сучасних технологій в тій або іншій країні визначається не тільки розвитком матеріальної бази, але головним чином - рівнем інтелектуалізації суспільства, його здатністю проводити, засвоювати і застосовувати нові знання [3]. Основні фактори, які здійснюють вплив на погіршення якості освіти в Україні можна поділити на внутрішні та зовнішні [10]. Але справжньою причиною негараздів в освіті $є$ те, що в управлінні освітою склався такий порядок формування та використання бюджету, який призводить до низької фінансової дисципліни i розмитості відповідальності за виконання бюджету. Незважаючи на щорічне зростання бюджетного фінансування освіти, понад 70\% цих коштів йде не на модернізацію та підвищення якості освітніх послуг, а на виплату заробітної плати та комунальні платежі, що значно скорочує інвестиційну спроможність фінансування освіти. При тому, що в таких країнах, як Австралія, Швеція, Норвегія, Словенія та Чехія рівень витрат на заробітну плату та комунальні платежі у загальній структурі видатків на вищу освіту не перевищує 60\%.

Забезпечення модернізації системи вищої освіти України вимагає збільшення обсягу державного фінансування до 8\% ВВП протягом найближчих п'яти років. Існують дослідження, відповідно до яких було визначено пряму залежність між часткою витрат на вищу освіту у національному доході країни та відносною величиною приросту середньорічного суспільного продукту. Незадовільне бюджетне фінансування освіти в Україні призводить до необхідності активного використання інших джерел фінансування, у тому числі й коштів самих студентів. Так, в Україні за рахунок власних коштів студентів державних закладів вищої освіти здійснюється погашення біля 55\% всіх витрат, пов'язаних з наданням освітніх послуг, при тому, що в США середній рівень погашення вартості отриманої освіти за рахунок власних коштів студентів не перевищує $14 \%$ загальної суми витрат.

Отже, обмеженість та неефективне використання бюджетних коштів, що спрямовуються на фінансування освіти в Україні стримують можливості інноваційного розвитку освітньої галузі та зменшують фактичний очікуваний соціально-економічний ефект від інвестування у людський капітал.

За кордоном проблема недостатнього фінансування вирішується шляхом переходу від переважного використання державних коштів до багатоканального фінансування на основі самостійного пошуку додаткових джерел, що приносять прибуток, який перетворюється на капітал, тобто процесу капіталізації. Наприклад, засадами досягнення високого рівня і якості вищої освіти в США є національне багатство, підтримка держави, а також традиція приватної благодійності, що заохочується податковою політикою держави.

Проте не менш вагомою є освітня стратегія самих ЗВО. Усі без винятку навчальні заклади абсолютно самостійні у вирішенні цих питань на досить конкурентному ринку освітніх послуг. Державна фінансова підтримка державних ЗВО становить не більше 
$30 \%$ усіх витрат. Решта коштів має бути мобілізована з інших джерел. Це принципово змінює природу фінансування вищої освіти. Альтернативою може стати лише банкрутство ЗВО, як це відбувається з будь-якими іншими суб'єктами ринку.

Університети стають економічними корпораціями та діють за принципами конкурентоспроможності та доходності. В межах університету «виживає» особа, яка може не лише створити нові знання, а й володіє здібностями вигідно їх продати в ринкових умовах. Завдяки системі розвинутої фінансової автономії, наприклад, факультет американського університету може розпоряджатися $80-85 \%$ зароблених коштів, відраховуючи решту на розвиток університету. Додаткове потенційне джерело фінансів для університетів - це навчання іноземних студентів, а також освіта дорослих громадян.

Зміна балансу між приватним і державним фінансуванням веде до прямого впливу ринкових сил на діяльність ЗВО і зменшує успадковану державну монополію на вищу освіту. Сучасні системи та механізми управління змінили відносини між вищими навчальними закладами, ринком та державою на користь ринку. Трансформація характеру і змісту освіти зумовила відповідну трансформацію структур управління університетів. Крім традиційних підрозділів університети створюють міждисциплінарні й багатопрофільні навчальні та навчально-дослідні лабораторії, дослідноконструкторські підрозділи, інноваційні підприємства, які виготовляють і реалізують інноваційну продукцію на основі результатів досліджень учених університету. Часто на їхній основі формуються структури, до завдань яких входить просування на ринок університетських розробок, випуск нової наукомісткої продукції, зміцнення зв'язків із промисловістю, створення науково-технічних стандартів, зокрема: : відділи захисту інтелектуальних прав та інтелектуальної власності, бюро технічного трансферу, малі інноваційні фірми.

Розвиваються різні форми інтеграції закладів вищої освіти і промислового сектору, такі як науково-виробничі підприємства, технополіси, спільні дослідні програми і центри. Що стосується України, то державна система фінансування вищої освіти і науки повинна враховувати глобальні тенденції у світі. Ефективність використання бюджетних коштів ЗВО має постійно перебувати в центрі уваги громадськості, а якість освіти повинна відповідати вимогам інноваційної економіки. Потрібно змінити технологію фінансування освіти, структуру іï витрат і надання послуг. Слід широко впроваджувати змішане фінансування освіти, відроджувати традиції меценатства, спонсорства. При цьому адресна допомога держави населенню для здобуття вищої освіти є важливою умовою подальшого розвитку цієї сфери.

В усіх випадках для України тут постають два не зовсім обнадійливих аспекти. По-перше, на що спрямувати інвестиції, не маючи реальної збалансованої програми розвитку та не визначившись з різким зменшенням ресурсо-енергопотоків. По-друге, що Україна може репрезентувати в цьому інноваційно-технологічному процесі на конкурентному ринку освітньох послуг.

У зв'язку з величезними втратами в нашій науці, а отже, й освіті, Україна мало що може самостійно робити на рівні сучасного «hi-tech». Сьогодні на це спроможні лише США, Японія, деякі європейські та інші заможні країни, де в уже створена належна наукова інфраструктура, яка забезпечує щорічне фінансування на одного 
науковця у розмірі 100 - 200 тис дол. У Свропі, як про завдання, говорять про суму 1 млн. євро щорічного фінансування на одного науковця. За нашої ж занедбаної наукової матеріально-технічної бази та недостатнього фінансування науки йде про суму близько 2 тис. дол. щорічно на науковця [11].

Виробництво нових знань є головним джерелом економічного розвитку. Так, у Норвегії і Данії інвестиції в сектор знань становлять 8,3\% ВВП; в США - 5,7\%, в Індії витрати складають 3,5\% ВВП. Відстаючи від розвинутих країн за інвестиціями в освіту, ми знижуємо іiі конкурентоспроможність. Країна може стати конкурентоспроможною лише у тому випадку, коли сировинна економіка зміниться на економіку знань [12].

Найбільш переконливими причинами зростання масовості вищої освіти можна вважати демографічну кризу (зниження народжуваності, старіння населення) та скорочення кількості робочих місць у виробничому секторі економіки. Система вищої освіти, зацікавлена у збереженні і розширенні своїх обсягів, в умовах скорочення абсолютної кількості абітурієнтів природним чином прагнуть до максимізації частки випускників середніх шкіл, які вступають до 3ВО. Дещо парадоксальним чином, деіндустріалізація також веде не до скорочення, а до розширення систем вищої освіти, оскільки дефіцит робочих місць загострює конкуренцію на ринку реальних і символічних кваліфікацій. Роботодавці дедалі частіше розглядають документ про вищу освіту як додатковий фільтр, що дає змогу відсікати надлишок потенційних працівників, котрі такого документа не мають.

Розширення системи вищої освіти у розвинутих країнах породжується об'єктивним попитом на вищу освіту, що існує в суспільстві. Вища освіта нині вважається необхідною умовою отримання в майбутньому кращої роботи та просування вгору щаблями соціальної драбини.

В Україні та інших пострадянських державах, де в минулому вища освіта справді була елітною і давала реальні соціальні переваги, подальшому розширенню системи вищої освіти сприяє й інерція суспільної свідомості. Крім того, у пострадянських суспільствах можливість отримання вищої освіти для більшості молодих людей стала частиною неписаного суспільного договору між владою i населенням: можливість отримання вищої освіти для молоді розглядається як своєрідна компенсація за незадовільне соціально-економічне становище, у якому протягом тривалого часу перебуває значна частина громадян.

3 огляду на це, заходи, спрямовані на скорочення системи вищої освіти чи можливостей iii отримати, неминуче будуть супроводжуватися невдоволенням i опором у суспільстві, додатково посилюваними протидією з боку самої системи вищої освіти. Масова вища освіта, попри всі іiі вади й негативні наслідки, дедалі більше стає соціальною реальністю на зразок письменності або доступу до телефонного зв'язку чи інтернету. Відтак, потрібно не обгрунтовувати необхідність скорочення системи вищої освіти, а знаходити механізми іiі ефективнішого використання в інтересах конкретних громадян, суспільства i держави в цілому. 
В освіті $є$ інша сторона - як структурний елемент соціуму, вона активно впливає на розвиток сучасного суспільства, в тому числі на його економіку. Так, що становище освітньої системи доленосне для самої країни, вона разом із наукою визначає ї майбутнє. Проте, як і раніше, бюджет України більш чим наполовину залежить від сировинних секторів промисловості. Навіть в Арабських Еміратах зменшується така залежність, вони повертаються до економіки знань, інноваційної економіки, яка передбачає наявність таких носіїв знань, як талановиті вчені, які виростають із обдарованих дітей. Емірати не шкодують грошей на пошук обдарованих дітей і їх освіту (звичайно безкоштовну) в кращих елітних університетах світу.

Очевидним найбільш негативним наслідком зростання ступеня масовості вищої освіти є знецінення, інфляція отримуваних кваліфікацій. Чим більше людей мають дипломи про вищу освіту, тим гострішою є конкуренція за робочі місця, для зайняття яких потрібен такий диплом. За умови відсутності зростання кількості робочих місць, кваліфікаційні вимоги природним чином підвищуються, що веде до подальшого підвищення вимог щодо якості освітніх кваліфікацій випускників 3ВО. Ситуація ще більше загострюється в умовах неналежного зв'язку між структурою підготовки спеціалістів у ЗВО і реальними потребами економіки, що являє собою застарілу проблему України. У цьому відношенні очевидною $є$ потреба у приведенні державного замовлення на підготовку спеціалістів у відповідність до реальних потреб національної економіки.

Висновки та перспективи подальших досліджень. Сучасна система вищої освіти, що повинна повною мірою відповідати вимогам часу, $є$ одним 3 найголовніших чинників зростання якості людського капіталу, генератором нових ідей, запорукою динамічного розвитку економіки і суспільства в цілому. Для того, щоб українська вища освіта по-справжньому ефективно виконувала ці важливі завдання, необхідне іiі оновлення з урахуванням актуальних світових тенденцій розвитку освіти у широкому соціально-економічному контексті.

3 метою максимального використання позитивного потенціалу сучасних глобальних тенденцій у розвитку освіти та подолання їх негативних наслідків необхідною є реалізація низки заходів, зокрема:

децентралізація системи вищої освіти;

реальна автономізація ЗВО (включно до виконання економічної діяльністі);

розвиток приватного сектора галузі вищої освіти 3 одночасним запровадженням ефективної системи оцінювання якості освіти;

поступова реструктуризація й оптимізація державного замовлення на підготовку спеціалістів 3 вищою освітою за участі роботодавців 3 метою приведення державного замовлення у відповідність до реальних потреб державного і приватного секторів національної економіки;

розвиток системи безперервної освіти протягом життя;

подальший розвиток експортного потенціалу вітчизняної вищої освіти 3 метою отримання позитивних економічних результатів, прискорення модернізації освіти та посилення впливу і престижу України у світі; 
активне впровадження у програми вищої освіти підприємницької складової, передусім у плані оволодіння студентами практичними навичками, необхідними для ведення самостійної економічної діяльності, а також отримання ними необхідних знань щодо законодавчих основ та практики бізнесу в Україні та за кордоном;

підвищення уваги до суспільнознавчого блоку вищої освіти та питань університетського самоврядування, від чого значною мірою залежить майбутня участь молодих людей у суспільно-політичному житті;

цілеспрямована просвітницька робота 3 метою об'єктивного інформування батьків і абітурієнтів, зацікавленої громадськості щодо цінності тих чи інших спеціальностей на вітчизняному і міжнародному ринку праці;

розширення автономності, тому що основною перешкодою процесу модернізації вітчизняної системи вищої освіти $\epsilon$ обмежена автономність вітчизняних 3ВО, що проявляється у надмірному державному адмініструванні напрямів їх діяльності.

Законодавче визначення «автономності» вітчизняних ЗВО (ст. 29 Закону України «Про вищу освіту») не відповідає основним принципам щодо автономності європейських закладів вищої освіти. Існуюча адміністративна та фінансова залежність 3ВО, особливо університетів, від органів державної влади зменшує ефективність роботи ЗВО, не сприяє усуненню дисбалансу між попитом та пропозицією на кваліфікованих фахівців на сучасному ринку праці та шкодить міжнародному іміджу вітчизняної вищої освіти.

Сьогодні перед державою i суспільством стоїть життєво важливе й невідкладне завдання не подальшого удосконалювання i реформування, a відновлення системи освіти на якісно новій основі. Україна повинна забезпечити пріоритетний розвиток освітнього сектору, оскільки це одна $з$ національних точок зростання країни.

\section{ЛIТЕРАТУРА}

1. Рівень освіти населення у відповідних вікових групах // Ukrstat.org - публікація документів Державної Служби Статистики. - URL: http://ukrstat.org/uk/operativ/operativ2010/gdn/sdh/dod_06.htm.

2. Офіційна статистика про розвиток вищої освіти та науково-технічної інформації в Україні. - URL: http//www.ukrstat.gov.ua.

3. Актуальні освітянські проблеми сьогодення. Інформатизація освіти. - URL: http://www.pravo.vuzlib.org/book_z809_page_7.html.

4. Буличева Н.А., Пивовар Ю. І. Сучасні правові та організаційні проблеми фінансування вищої освіти в Україні. - URL: http://radnuk.info/statti/255-finpr/3593-2010-01-29-18-50-22.html.

5. Освіта України в XXI столітті: проблеми та перспективи розвитку. URL:http://ua.textreferat.com/referat-13090-1.html.

6. Архипова С.П. Якість освіти у контексті вимог сучасності. - URL: http://archive.nbuv.gov.ua/portal/soc_gum/vchu/N135/N135p011-014.pdf.

7. Богачевська I.B., Карпенко М.М. Болонський процес в Україні: стан та проблеми реалізації. - URL: http://old.niss.gov.ua/Monitor/May08/09.htm.

8. Кудрявцева О.А. Тестування як засіб перевірки якості знань 3 дошкільної педагогіки студентів педагогічного університету. -URL: http://archive.nbuv. gov.ua/portal/Soc_Gum/NiO/2009_7/2_rozdil/Kudryavtseva.htm. 
9. Радомська Л.А., Стадній А.С. Українська система вищої освіти: переваги й недоліки болонського процесу. - URL: http://conf.vntu.edu.ua/humed/2010/txt/Radomska_Stadniy.php.

10. Турчин Я.Б. Болонський процес та зона вільної торгівлі з СС: спільне для України?! URL: http://blogs.korrespondent.net/users/blog/areal90/a88554.

11. Хайнацька Ю.Ю., Гордєєва Т.А. Аналіз фінансування видатків на освіту в Україні. URL http://intkonf.org/haynatska-yuyu-gordeeva-ta-analiz-finansuvannya-vidatkiv-na-osvitu-vukrayini/.

12. Боголіб T.M. Розвиток інноваційної економіки і елітна освіта. - URL: http://www.disserlib.com/left_menu\%20papka/rozvitok.php.

\section{REFERENCES}

1. The level of education of the population in the relevant age groups // Ukrstat.org - publication of documents of the State Statistics Service of Ukraine. - URL: http://ukrstat.org/uk/operativ/operativ2010/gdn/sdh/dod_06.htm.

2. Official statistics on the development of higher education and scientific and technical information in Ukraine. - URL: http // www.ukrstat.gov.ua.

3. Current educational problems of today. Informatization of education. - URL: http://www.pravo.vuzlib.org/book_z809_page_7.html.

4. Bulycheva NA, Pivovar Yu. I. Modern legal and organizational problems of financing higher education in Ukraine. - URL: http://radnuk.info/statti/255-finpr/3593-2010-01-29-18-50-22.html.

5. Education of Ukraine in the XXI century: problems and prospects of development. - URL: http://ua.textreferat.com/referat-13090-1.html.

6. Arkhipova S.P. Quality of the world in the context of modern requirements. - URL: http://archive.nbuv.gov.ua/portal/soc_gum/vchu/N135/N135p011-014.pdf.

7. Bogachevska I.V., Karpenko M.M. Bologna process in Ukraine: state and problems of implementation. - URL: http://old.niss.gov.ua/Monitor/May08/09.htm.

8. Kudryavtseva O.A. Testing as a means of checking the quality of knowledge in preschool pedagogy of students of pedagogical university. - URL: http://archive.nbuv.gov.ua/portal/Soc_Gum/NiO/2009_7/2_rozdil/Kudryavtseva.htm.

9. Radomska L.A., Stadniy A.S. Ukrainian system of higher education: advantages and disadvantages of the Bologna process. URL:http://conf.vntu.edu.ua/humed/2010/txt/Radomska_Stadniy.php.

10. Turchyn J.B. Bologna process and free trade zone with the EU: common for Ukraine ?! URL: http://blogs.korrespondent.net/users/blog/areal90/a88554.

11. Khaynatska Yu.Yu., Gord€€va T.A. Analysis of financial views for coverage in Ukraine. URL http://intkonf.org/haynatska-yuyu-gordeeva-ta-analiz-finansuvannya-vidatkiv-na-osvitu-vukrayini/.

12. Bogolib T.M. Development of the innovative economy and innovative education. - URL: http://www.disserlib.com/left_menu\%20papka/rozvitok.php.

\section{РЕЗЮМЕ}

Игорь Плохута, Национальный университет обороны Украины имени Ивана Черняховского

Михаил Орда, кандидат технических наук, старший научный сотрудник Национальный университет обороны Украины имени Ивана Черняховского

\section{Общие проблемы и перспективы развития высшего образования в Украине}


В статье рассмотрено существующее состояние, и общие проблемы, связанные с необходимостью разработки и внедрения мер для обеспечения качества высшего образования 8 Украине, определения стратегии развития высших учебных заведений, уделено внимание перспективам развития высшего образования, исходя из общих реформ образовательной cферы.

Ключевые слова: образование; высшее образование; учебный прочесс; государственное регулирование высшего образования.

\section{SUMMARY}

Igor Plokhuta,

National Defense University of Ukraine named after Ivan Cherniakhovskyi

Mikhailo Orda,

$\mathrm{PhD}$ (technical sciences), Senior Researcher

National University of Defence of Ukraine named after Ivan Chernyakhovskyi

\section{General problems and prospects of higher education in Ukraine}

Introduction. The state, problems associated with the need to develop measures to ensure the quality of higher education in Ukraine, the need to choose a strategy for the development of higher educational institutions; prospects for the development of higher education, based on the general reforms of the educational sphere.

Purpose. Development of measures to strengthen the role of the state in improving the quality of higher education in Ukraine, taking into account all the capabilities of higher education institutions and the needs of employers in professional and qualified professionals.

Methods. The study was conducted using the following theoretical methods: systematic analysis of domestic and international experience in solving problems of higher education, induction and deduction, comparison, generalization and systematization.

Results. We considered the present, problems and prospects for the development of military education in Ukraine. We have demonstrated the key solutions and solutions to this problem.

Originality. Today, one of the most important issues of scientific knowledge and practical implementation of modern principles of higher education is training in Ukrainian universities on the basis of the European approach. These issues should be addressed in connection with the national law on education and regulations for the development of the entire education system. Meanwhile, there are many problems in this area, both with the long process of reforming higher education in Ukraine and with the need to adapt to the norms and standards of the EU and the US, taking into account the experience of these countries.

Conclusion. In order to improve the situation in the field of education and increase its prestige, it is necessary to mobilize the efforts of employers, universities and the state. establishing strict state control over them, taking into account the Constitution of Ukraine.

Key words: education; higher education; educations process; state regulation of higher education. 